\title{
ECOLOGICAL AGRICULTURE IN POLAND
}

Intensive agricultural economy, characterized by a high use of chemicals, is one of the reasons of degradation of natural environment. It is estimated that in Poland on some 6 per cent of arable land production should be ceased due to ecological pollution of the agroecosystems (Michna, 1993).

Ecological agriculture is one of the factors that can successfully counteract degradation of natural environment caused by intensified agricultural production. Its aim is not only to supply consumers with food of high biological value, but also to create conditions for a permanent development of the agroecosystem, i.e. for self-regeneration of its production abilities. The fundamental idea of ecological agriculture is to maintain sustainable plant and animal production on a farm, which creates the possibility of keeping the circulation of organic matter closed within the farm. Owing to this such farms use up less energy and are less dependent on non-regenerative resources, while at the same time they pertain to the growth of different, more varied agrocenoses.

In Poland ecological agriculture has been functioning officially since 1990, when the first ecological farms were registered. At present there are 225 ecological farms which are in possession of a certificate given to them by EKOLAND Association. ${ }^{1}$

An agricultural farm can apply for a certificate of an ecological farm if it fulfills certain criteria: production, organizational and environmental ones.

The production criteria determine which means of production may be used in the process of production. The organizational criteria specify the relations between the ecological farm and EKOLAND Association as the organization determining the criteria of ecological production, controlling their reinforcement, and giving certificates of ecological farms.

The environmental criteria determine that the ecological farms:

- should be situated at such a distance from dust emitting plants, from

\footnotetext{
1 EKOLAND - Association of Food Producers by Ecological Methods, was registered in 1989 and is the only organization in Poland which can attest the farms that fulfil the criteria of ecological agriculture as ecological farms. EKOLAND is also a member of International Federation of Ecological Agriculture IFOAM.
} 
dumps of metal wastes and from large animal farms which produce dung, that one can exclude the possibility of their permanent pollution;

- are not to be situated within protection zone of industrial plants;

- should be localized at a distance of at least 100 metres from a heavy traffic road (over 500 vehicles per hour) and should be separated from such a road by a thick hedge;

- must not be characterized by heavy metals content exceeding the accepted standards, which are:

$\begin{array}{lllllll}\mathrm{Pb} & \mathrm{Cd} & \mathrm{Ni} & \mathrm{Cr} & \mathrm{Hg} & \mathrm{Cu} & \mathrm{Zn} \\ 100 & 2 & 50 & 100 & 1.5 & 100 & 200 \mathrm{mg} / \mathrm{kg} \text { dry soil }\end{array}$

- should be situated at such a distance from water-courses with classless water overflowing in spring that their negative influence on arable land can be definitely excluded. The quality of underground water, well water and tap water must conform to the national standards both as concerns its chemical content and microbiological indices.

Thus, the environmental criteria of ecological agriculture set clear limits to the localization of ecological farms. Taking into account only soil pollution of industrial origin (about 5-6 per cent of arable land), their dispersed character and a certain protection zone, one should exclude from ecological agricultural production about 15 per cent of arable land (Sołtysiak, 1993).

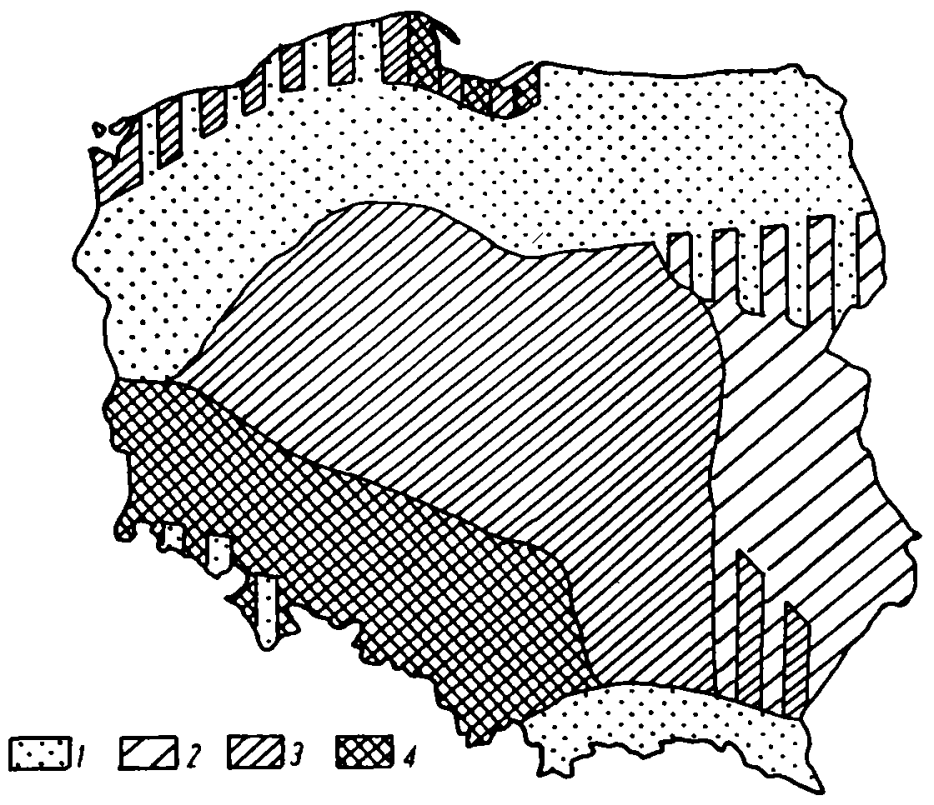

Fig. 1. Ecological regionalization of Poland

1 - regions of very favourable conditions for the development of ecological agriculture

2 - regions of satisfactory conditions for the development of ecological agriculture

3 - regions of poor conditions for the development of ecological agriculture

4 - regions of unfavourable conditions for the development of ecological agriculture

Source: Kozłowski S. (1994) 
The best conditions for the development of ecological agriculture can be found in the regions characterized by highly valuable natural environment, requiring special protection against ecological dangers which can appear as a result of intensive agricultural production. According to ecological

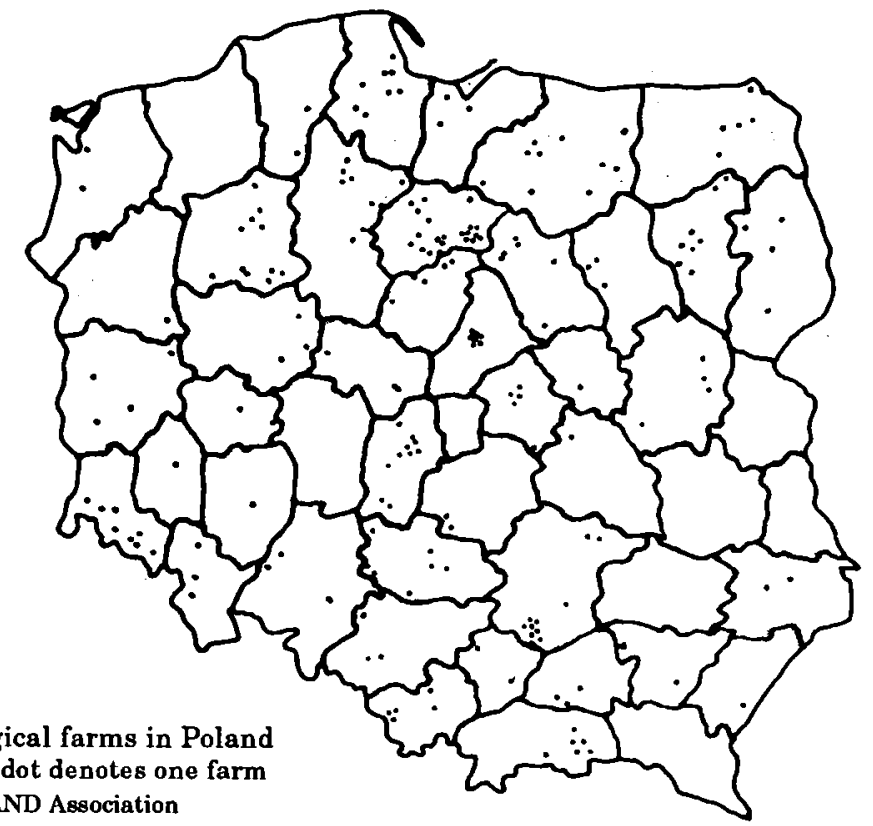

Fig. 2. Ecological farms in Poland - one dot denotes one farm Source: EKOLAND Association

regionalization of Poland ${ }^{2}$ such regions are first of all the areas of the lake districts and of the Bieszczady Mountains, the latter situated in the south-east of the country. Ecological agriculture, with its chief aim to increase biological diversification and hence to appropriately shape landscape architecture, can well contribute to the growth of recreational values of these regions.

The national parks and landscape parks as well as their immediate surroundings create good chances for the development of ecological agricul-

Ecological farms in Poland

\begin{tabular}{|c|c|c|}
\hline Year & $\begin{array}{c}\text { Number of attested } \\
\text { farms }\end{array}$ & $\begin{array}{c}\text { Area } \\
\text { (in hectares) }\end{array}$ \\
\hline 1990 & 27 & 300 \\
\hline 1991 & 49 & 550 \\
\hline 1992 & 94 & 1040 \\
\hline 1993 & 174 & 2000 \\
\hline 1994 & 225 & 3540 \\
\hline
\end{tabular}

Source: data of EKOLAND Association.

ture in Poland. On these protected areas it is required by law that man's activity of any kind should be subordinate to the environment. That is why ecological agriculture ought to be developed there. As an example we can

2 In the course of ecological regionalization of Poland not only natural values of the environment were taken into account, but also the level of urbanization and industrialization, and, following from them, the dangers threatening the environment. 
mention here the planned development of a functional area called "The Green Lungs of Poland", which includes the Białowieza National Park, and the Wigry National Park, two landscape parks: the Mazurian Park and Narwia Park, as well as numerous nature reserves.

The least favourable conditions for popularizing ecological agriculture occur in the south-western part of Poland and in some central voivodships, i.e. in the regions in which excessive anthropopression on natural environment (large concentration of population, production and services) has resulted in its degradation.

From comparison of Figs. 1 and 2 it can be seen that ecological farms in Poland are not always situated in the areas most favourable for their development. For instance, in south-western Poland ecological farms are functioning in most parts of the regions in spite of considerable pollution of natural environment there. On the other hand, in north-eastern Poland the distribution of ecological farms is in line with the areas favourable for the development of ecological agriculture.

It is the access to information rather than natural conditions that is mostly responsible for the distribution of ecological farms. As a rule they appear in close vicinity of powerful centres of information concerning ecological agriculture, or in the areas where other ecological farms had already existed. This is largely due to the fact that ecological agriculture has not yet been included in the government plan, such that would, among other things, provide the farmers running ecological farms with credits on preferential terms and tax reductions, particularly in the regions of special natural advantages.

Another factor necessary for the development of ecological agriculture is pro-ecology oriented education. No development in this field will be possible unless the farmers are well prepared for it. Agricultural production by ecological methods requires that the farmers have a considerable amount of knowledge, not only in the field of agrotechnics but also nature itself as well as ecology in the broad meaning of the term. So far, ecological consciousness of rural population in Poland is rather low.

\section{REFERENCES}

Mich n a W, 1993, Raporty wyjściowe do studium pt. "Proekologiczne zorientowanie polityki rolnej $w$ Polsce na przetomie $X X i$ XXI wieku". Synteza (Preliminary reports to a study ${ }_{n}$ Pro-ecological orientation of agricultural policy in Poland at the turn of the 20th and 21st centuries". A synthesis), Warszawa, IERiGZ.

Soltysiak U., 1993, Rolnictwo ekologiczne w Europie i w Polsce (Ecological agriculture in Europe and Poland), in: Preliminary reports to a study "Proecological orientation of agricultural policy in Poland at the turn of the 20th and 21st centuries", Warszawa: IERiGZ, vol., III, pp. 91-98. 